Thorax (1967), 22, 387.

\title{
Heterograft aortic valve replacement: initial follow-up studies
}

\author{
M. F. O'BRIEN ${ }^{1}, J$ J K CLAREBROUGH, I. G. MCDONALD, \\ G. S. HALE, H. S. BRAY, AND J. F. CA D E \\ From St. Vincent's Hospital, Melbourne, Australia
}

\begin{abstract}
Twenty-three patients have had calf or pig heterograft aortic valve replacements. Eight of these patients have required Starr-Edwards mitral ball-valve prostheses for associated mitral valve disease. There have been two hospital deaths and one late death. The 20 surviving patients have shown symptomatic improvement. Clinical evidence of incompetence is present in one patient. Pre-operative and post-operative ciné-aortograms show valve mobility with a wide central orifice. Heterografts have the advantages of homografts in being free from thromboembolism and from the need for anticoagulants; they exhibit some resistance to infection as compared with prosthetic valves. We think that heterografts, because of their wider range of size, can offer a better haemodynamic result with little clinical aortic incompetence. The long-term fate of aortic valve heterografts is not known with certainty, although the durability of homografts is better known. There is a possibility of late degeneration or rupture. If the valve continues to function normally, then it would be justifiable to recommend operation at an earlier stage in the progression of the patient's disease. At present, despite encouraging early results, we think the use of heterografts should be limited, like that of other prostheses, to those patients who show severe cardiac disability.
\end{abstract}

Pig and calf aortic valves have been used as heterograft replacements in 23 patients with severe aortic valve disease at St. Vincent's Hospital, Melbourne (O'Brien and Clarebrough, 1967). This paper records our assessment of these valves, and our views on the current indications for their use, their functional performance, and their place as a possible alternative to other types of aortic valve. Work in this field was first reported from Paris by Binet, Duran, Carpenter, and Langlois (1965), and our initial studies were reported in 1966 (O'Brien and Clarebrough). There are several features of heterografts which make us feel justified in using them.

Firstly, no heterograft has been complicated by embolism. This advantage, shared by homograft valves, makes anticoagulants unnecessary. Although anticoagulants have lessened the thromboembolic complications of prosthetic materials, their use carries a small morbidity and mortality, so that lack of need for such therapy is one of the most appealing features of organic valves. In women of child-bearing age, and particularly in

${ }^{1}$ Present address: Chermside Chest Hospital, Brisbane, Australia patients from country centres, where safe and effective anticoagulant control is not always obtainable, we have found heterografts to be of great advantage.

Secondly, the incidence of infection of heterografts and homografts is much lower than that of prosthetic valves. It is likely that formaldehydepreserved valves offer some resistance to early infection (O'Brien and Clarebrough, 1966).

Thirdly, we think the heterograft valve should give a better haemodynamic result than either the prosthetic or homograft valve. In patients with a small aortic root, the heterograft has a wider valve orifice than that of the small prosthetic valve. Since a wide range of suitable sizes of the graft is readily obtainable (Fig. 1), the incidence of aortic incompetence with the technique employed should be negligible and less than that reported by the homograft workers (Barratt-Boyes, 1964; Barratt-Boyes, Lowe, Cole, and Kelly, 1965). However, Ross (1966) has recently reported a significant reduction in the incidence of incompetence, and in the early operative experience of homografts it was not fully appreciated that ample redundancy of leaflet tissue was necessary for full 


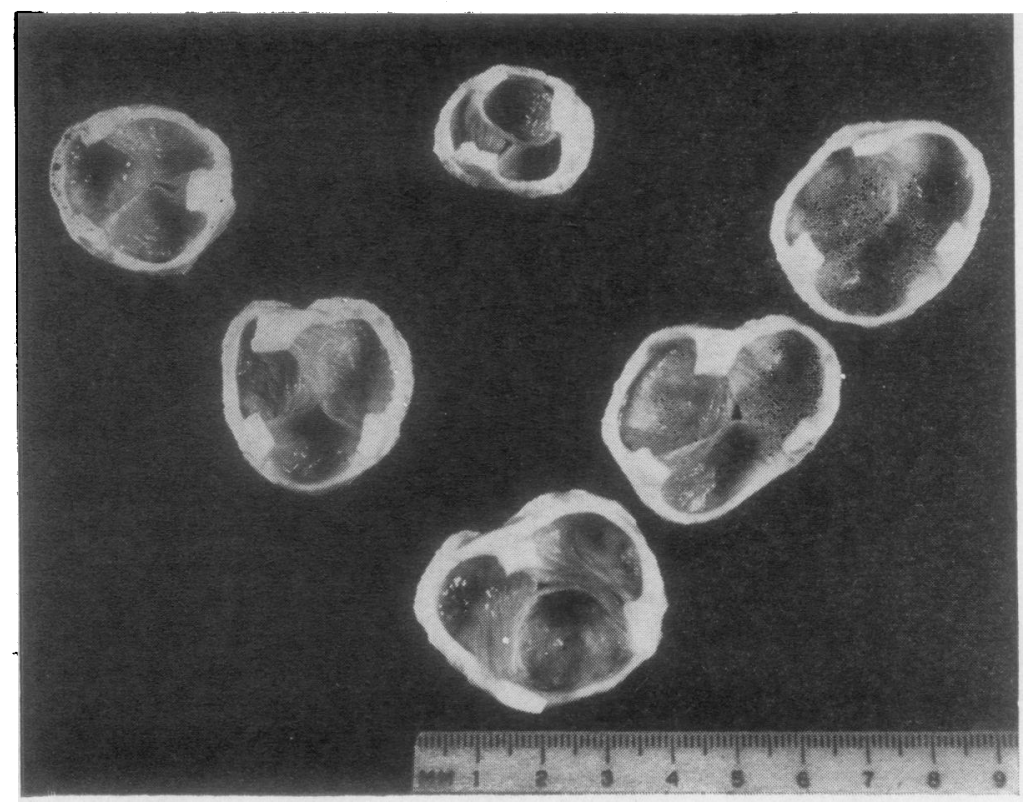

FIG. 1. The range of the more commonly used size $\overrightarrow{\mathrm{B}}$ of pig and calf heterograftio Larger sizes are readily ober tainable.

competence (Smith, 1967). At present one patient in our series has a soft diastolic murmur without peripheral signs, suggesting that the incompetence is of little functional significance.

Fourthly, organic valve tissue has shown its durability for at leaet eight and a half years in the follow-up reports (Kerwin, Lenkei, and Wilson, 1962 ; Bigelow, Yeo, Aldridge, Heimbecker, and Murray, 1964) of homograft valves inserted in the descending thoracic aorta in 1956 (Murray, 1956). Although this series is small, no prosthetic aortic valve has been followed for a comparable period.

Lastly, less important reasons for the preference for organic valves include the low cost of establishing a readily available valve bank and the fact that patients are unaware of the movements of these valves, whereas the clicking noise of a ball-valve prosthesis is sometimes disconcerting.

Against these advantages should be set the unknown long-term fate of aortic valve heterografts, and particularly the possibility of calcification and rupture.

\section{VALVE BANK AND TECHNIQUE}

The heterograft valve bank was established in 1965 and the first operation was performed in February 1966 (O'Brien and Clarebrough, 1966). The method of establishing the animal valve bank has been previously presented (O'Brien, 1967).
The non-sterile valves are collected immediate after the animals have been killed at the abattoir They are excised in a tissue block leaving attached a few centimetres of aorta above and a small ri苗 of myocardial muscle and mitral valve belo Wool is packed into the aortic sinuses to retai the shape of the cusps and valve annulus The valves are preserved and sterilized with buffered acid formaldehyde solution (Paneth an O'Brien, 1966), which is periodically changed according to the $p \mathrm{H}$ measurements of the flui\& during the next several weeks. The mitral valve, aortic wall (except for a 5- to 6-mm. rim), and all of the ventricular muscle are then dissected from the valve. The effective area of mobile value tissue out to the annulus or aortic rim is increase (Figs 2A and B) by removal of all ventriculars muscle which supports the base of two leafle (most human aortic valves are not so supported) The aortic wall and annulus around its entife circumference constitute the rim for suturing Sixteen of the implanted valves remained in thbs formaldehyde solution prior to use for three or more months (Table $\mathrm{I}$ ). In cases 10 and 18 the valve was in the solution for six weeks.

At operation, four or five valves of varying sizes covering the anticipated range, as assessed on ciné aortography, are soaked in Ringer's solution fơ approximately one hour before cardiopulmonaf bypass is started. After excision of the diseased aortic valve, and after preparing an adequate be 
T A B L E I

DURATION OF FORMALDEHYDE PRESERVATION PRIOR TO CLINICAL USE AND MAJOR COMFLICATIONS

\begin{tabular}{|c|c|c|c|c|c|c|c|c|}
\hline \multirow{2}{*}{$\begin{array}{l}\text { Case } \\
\text { No. }\end{array}$} & \multirow{2}{*}{\multicolumn{2}{|c|}{ Sex/Age }} & \multirow{2}{*}{ Diagnosis } & \multirow{2}{*}{$\begin{array}{l}\text { Type of Aortic } \\
\text { Heterograft } \\
\text { and Operation }\end{array}$} & \multirow{2}{*}{$\begin{array}{c}\text { Duration } \\
\text { in } \\
\text { Formalde- } \\
\text { hyde } \\
\text { (months) }\end{array}$} & \multicolumn{2}{|c|}{$\begin{array}{l}\text { Obturator } \\
\text { Size of Annulus } 1\end{array}$} & \multirow{2}{*}{ Post-operative Complications } \\
\hline & & & & & & Host & $\begin{array}{c}\text { Hetero- } \\
\text { graft }\end{array}$ & \\
\hline 1 & $\mathbf{M}$ & 47 & Calcific A.S., A.I., mild & Pig & 4 & 9 & 10 & Wound infection \\
\hline $\begin{array}{l}2 \\
3\end{array}$ & & $\begin{array}{l}26 \\
28\end{array}$ & $\begin{array}{l}\text { A.S.A., A.I., M.I. } \\
\text { A.I., M.I. }\end{array}$ & $\begin{array}{l}\text { Pig + Starr mitral } \\
\text { Calf + Starr mitral }\end{array}$ & $\begin{array}{l}2 \\
2 \frac{1}{2}\end{array}$ & $\begin{array}{r}8 \\
10\end{array}$ & $\begin{array}{r}9 \\
11\end{array}$ & $\begin{array}{l}\text { Nil } \\
\text { Died ( } 2 \text { months); infective throm- } \\
\text { bo-embolism (mitral pros- } \\
\text { thesis) }\end{array}$ \\
\hline $\begin{array}{l}4 \\
5\end{array}$ & & $\begin{array}{l}49 \\
40\end{array}$ & $\begin{array}{l}\text { A.S., A.I. } \\
\text { A.I., M.I. }\end{array}$ & $\begin{array}{l}\text { Calf } \\
\text { Calf }+ \text { mitral annulo- }\end{array}$ & $\begin{array}{l}3 \\
3 \frac{1}{2}\end{array}$ & $\begin{array}{r}9 \\
12\end{array}$ & $\begin{array}{l}10 \\
13\end{array}$ & $\begin{array}{l}\mathrm{Nil} \\
\mathrm{Nil}\end{array}$ \\
\hline $\begin{array}{l}6 \\
7\end{array}$ & & $\begin{array}{l}45 \\
61\end{array}$ & $\begin{array}{l}\text { A.I., M.S., mild C.A.D. } \\
\text { Calcific A.S., A.I., severe } \\
\text { C.A.D. }\end{array}$ & $\begin{array}{l}\text { Calf }+ \text { mitral valvotomy } \\
\text { Calf }\end{array}$ & $\begin{array}{l}4 \\
4\end{array}$ & $\begin{array}{r}10 \\
8\end{array}$ & $\begin{array}{r}11 \\
9\end{array}$ & $\begin{array}{l}\text { Nil } \\
\text { Severe 'post-perfusion mononuc- } \\
\text { leosis' }\end{array}$ \\
\hline $\begin{array}{r}8 \\
9 \\
10 \\
11 \\
12\end{array}$ & $\begin{array}{l}\mathbf{F} \\
\mathbf{M} \\
\mathbf{F} \\
\mathbf{F} \\
\mathbf{M}\end{array}$ & $\begin{array}{l}18 \\
36 \\
32 \\
42 \\
37\end{array}$ & $\begin{array}{l}\text { A.I. } \\
\text { Calcific A.S., A.I. } \\
\text { A.S., A.I., M.S., M.I. } \\
\text { A.I., M.S., M.I. } \\
\text { Calcific A.S., A.I., severe } \\
\text { C.A.D. }\end{array}$ & $\begin{array}{l}\text { Calf } \\
\text { Calf } \\
\text { Pig }+ \text { Starr mitral } \\
\text { Calf + Starr mitral } \\
\text { Calf }\end{array}$ & $\begin{array}{l}4 \\
5 \\
1 \frac{1}{2} \\
6 \\
3\end{array}$ & $\begin{array}{l}13 \\
10 \\
10 \\
10 \\
10\end{array}$ & $\begin{array}{l}13 \\
11 \\
11 \\
11 \\
11\end{array}$ & $\begin{array}{l}\text { Wound infection } \\
\text { Nil } \\
\text { Nil } \\
\text { Schizophrenia exacerbated } \\
\text { Operative haemorrhage; cardiac } \\
\text { arrest; cerebral damage (died } \\
\text { 2nd day) }\end{array}$ \\
\hline 13 & $\mathbf{M}$ & 58 & Calcific A.S., mild C.A.D. & Calf & 3 & $\begin{array}{l}11 \\
\text { Bicuspid }\end{array}$ & 13 & $\mathrm{Nil}^{\text {2nd day) }}$ \\
\hline $\begin{array}{l}14 \\
15\end{array}$ & & $\begin{array}{l}43 \\
50\end{array}$ & $\begin{array}{l}\text { A.I., M.S., M.I. } \\
\text { A.S., A.I., M.S., M.I., } \\
\text { mild C.A.D. }\end{array}$ & $\begin{array}{l}\text { Pig + Starr mitral } \\
\text { Calf }+ \text { Starr mitral }\end{array}$ & $2 \frac{1}{2}$ & $\begin{array}{c}9 \\
11\end{array}$ & $\begin{array}{l}10 \\
13\end{array}$ & $\begin{array}{l}\text { Nil } \\
\text { Nil }\end{array}$ \\
\hline $\begin{array}{l}16 \\
17\end{array}$ & $\begin{array}{l}\mathbf{M} \\
\mathbf{M}\end{array}$ & $\begin{array}{l}58 \\
62\end{array}$ & $\begin{array}{l}\text { Calcific A.S. } \\
\text { Calcific A.S. }\end{array}$ & $\underset{\text { Calf }}{\text { Pig }}$ & $2 \frac{1}{2}$ & $\begin{array}{l}7 \\
10 \\
\text { Bicuspid }\end{array}$ & $\begin{array}{r}9 \\
12\end{array}$ & $\begin{array}{l}\text { Nil } \\
\text { Haemorrhage; renal failure; } \\
\text { cardiac arrest (died 11th day) }\end{array}$ \\
\hline $\begin{array}{l}18 \\
19\end{array}$ & $\mathbf{M}$ & $\begin{array}{l}67 \\
59\end{array}$ & $\begin{array}{l}\text { Calcific A.S. } \\
\text { A.I., M.S., M.I. }\end{array}$ & $\stackrel{\text { Pig }}{\text { Calf }}+$ Starr mitral & $4^{\frac{1}{2}}$ & $\begin{array}{c}9 \\
10 \\
\text { Bicuspid }\end{array}$ & $\begin{array}{l}10 \\
12\end{array}$ & $\begin{array}{l}\text { Nil } \\
\text { Nil }\end{array}$ \\
\hline 20 & $\mathbf{M}$ & 58 & Calcific A.S. & Calf & 5 & $\begin{array}{l}10 \\
\text { Bicuspid }\end{array}$ & 12 & Nil \\
\hline $\begin{array}{l}21 \\
22 \\
23\end{array}$ & $\begin{array}{l}\mathbf{M} \\
\mathbf{M} \\
\mathbf{M}\end{array}$ & $\begin{array}{l}35 \\
51 \\
38\end{array}$ & $\begin{array}{l}\text { A.I. } \\
\text { A.I. } \\
\text { A.S., A.I., M.S., M.I. }\end{array}$ & $\begin{array}{l}\text { Calf } \\
\text { Pig } \\
\text { Calf }+ \text { Starr mitral }\end{array}$ & $\begin{array}{l}5 \\
2 \frac{1}{2} \\
5\end{array}$ & $\begin{array}{l}13 \\
11 \\
10\end{array}$ & $\begin{array}{l}14 \\
12 \\
11\end{array}$ & $\begin{array}{l}\mathrm{Nil} \\
\mathrm{Nil} \\
\mathrm{Nil}\end{array}$ \\
\hline
\end{tabular}

A.S. $=$ Aortic stenosis; A.I. $=$ aortic incompetence; C.A.D. $=$ coronary artery disease $;$ M.S. $=$ mitral stenosis; M.I $=$ mitral inccmpetence 1 The obturator sizes given are measured with Starr-Edwards obturator cups.
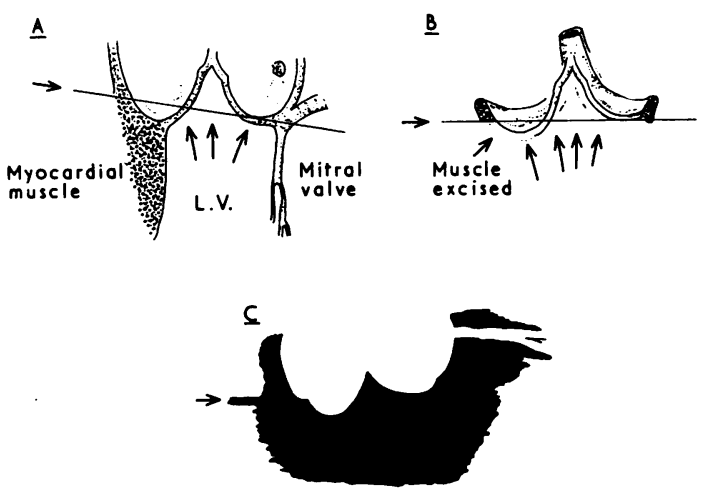

FIG. 2. ( $A$ and $B$ ) After excision of ventricular muscle, the valve orifice is increased and the aortic annulus becomes the entire rim of the valve. The cusps, particularly the right coronary leaflet, 'prolapse' below a horizontal line drawn through the aortic rim on each side. (C) A diagrammatic representation of the aortogram explains the 'prolapse' appearance of the cusps in the ciné-aortogram (Fig. 7B). the diameter of the valve orifice is measured with the Starr-Edwards obturator cups. A heterograft which will pass comfortably over the selected obturator is then implanted. By choosing a slightly larger valve with this technique of measurement, the risk of residual aortic incompetence is reduced. Table I outlines the size of host and heterograft used in this series of patients. Occasionally, a much larger valve is used to replace bicuspid valves where it is necessary to have a large heterograft cusp occupy half of the circumference of the host aortic valve rim. In this way excess leaflet tissue is present, but it is so thin and pliable that no obstruction to flow seems to occur. Cases 13, 17,19 , and 20 had congenital or acquired bicuspid valves and, as shown in Table $I$, a heterograft two sizes larger than the aortic root was implanted in each case. The valve is sutured to the host aortic annulus using a continuous suture with wide bites. Interrupted sutures (cases 4 and 23) are inserted in areas where the excision of calcium leaves the rim irregular. We have no reason to change this technique, nor is a double suture line 
considered necessary. It is stressed that considerable care is taken in the placement of each suture.

Seven pig and 16 calf valves have been used. No preference for either exists. Most of the large valves in the bank are calf in origin, although recently larger pig valves have been obtained. At operation the unselected valves are returned to their formaldehyde bottles and may be used subsequently.

\section{CLINICAL EXPERIENCES}

It has been the policy to recommend surgery only to patients with at least moderately severe symptomatic valve disease. Twenty-three patients have had aortic heterograft replacements (Table II). In 10 there was associated mitral valve diseasemitral stenosis in one (valvotomy), considerable dilatation of the mitral annulus secondary to severe aortic incompetence in one (annuloplasty), and severe pure mitral incompetence or mixed disease in eight patients (double valve replacement using the Starr-Edwards mitral ball-valve pros-

\section{T A B L E I I}

OPERATION AND MORTALITY FIGURES

\begin{tabular}{c|l|c|c}
\hline \multirow{2}{*}{$\begin{array}{c}\text { No. of } \\
\text { Patients }\end{array}$} & Operation & \multicolumn{2}{|c}{ Mortality } \\
\cline { 2 - 4 } & $\begin{array}{c}\text { Ao. H.+Starr-Edwards } \\
\text { mitral ball-valve prosthesis }\end{array}$ & 0 & Late \\
\hline 2 & $\begin{array}{c}\text { Ao. H. +mitral valvotomy } \\
\text { Ao. H. + mitral annuloplasty }\end{array}$ & 0 & $\begin{array}{c}1 \\
(2 \text { mths) }\end{array}$ \\
\hline 13 & Ao. H. & $\begin{array}{c}2 \\
\text { (2nd and } \\
11 \text { th days) }\end{array}$ & 0 \\
\hline
\end{tabular}

Total 23 (7 pig and 16 calf)

Ao. $\mathbf{H} .=$ Aortic heterograft valve.

thesis). Thus 13 patients have had isolated aortic valve surgery. In three cases the host aortic root was small, allowing only a size 8,8 , and 7 Starr obturator cup respectively to pass into the ventricular cavity. The heterograft orifice in each case was larger than that of a prosthesis of comparable size, across which there may be a pressure gradient.

Routine pre-operative selective coronary cinéangiography revealed coronary artery disease in seven patients, which was severe in two (cases 7 and 12).

Anticoagulants have been given to those patients with the additional mitral ball-valve prosthesis.
IMMEDIATE OPERATIVE RESULTS Of the 23 patients, 21 survived and left hospital. The majority of $\frac{\overline{\bar{C}}}{\bar{\rho}}$. patients with single valve replacements were dis- $\frac{\rho}{\sigma}$ charged home within two weeks of operation. One $\varrho$ patient (case 3) was readmitted and died two \% months after operation. Hence follow-up was $\vec{\circ}$ available on 20 patients.

Most of the patients have had no major com- $\overrightarrow{\vec{\omega}}$ plications (Table I), and, in particular, heart block has not occurred. The immediate post-operative $\vec{x}$ course was essentially the same as after previous prosthetic valve replacements.

The two hospital deaths (cases 12 and 17) $\omega_{\infty}$ occurred on the second and eleventh post- $\checkmark$

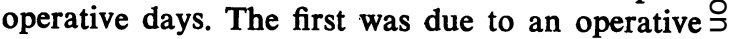
accident. Just before closing the median sterno- $\vec{c}$ tomy wound, while checking haemostasis around $\mathbb{\Phi}$

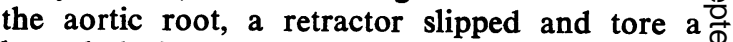
large hole in the right atrium at the atrio-aortic $\frac{1}{3}$ groove. Cardiac arrest occurred while attempts $\mathbb{\Phi}$ were made to control the haemorrhage. Cardiac resuscitation and haemostasis were eventually $\mathscr{\odot}$ achieved and post-operatively the haemodynamic. status and heterograft valve function were excellent. This 37-year-old patient, who also had severe coronary artery disease, died from irreversible cerebral damage.

The second hospital death occurred in a patient $\stackrel{\circ}{\circ}$ who developed anuria following post-operative $\vec{\overrightarrow{ }}$ mediastinal and retroperitoneal haemorrhage. $\mathrm{He} \frac{3}{3}$ had an unexpected cardiac arrest while showing clinical improvement after peritoneal dialysis. In this patient the heterograft valve functioned well. The only late death in this series occurred at two 을 months in a patient (case 3 ) who was readmitted $\underset{\times}{\stackrel{\Xi}{*}}$ with a wound infection due to Staphylococcus $\dot{0}$ pyogenes. Septicaemia, infective emboli, mycotic cerebral aneurysms, and a massive fatal cerebral $\delta$ haemorrhage followed. Although there was a large infective thrombus on both surfaces of the 윽 Starr-Edwards mitral prosthesis, it was striking that the heterograft was free of either thrombus or infection.

A detailed microscopic examination of these N three valves will be reported separately (O'Brien, $N$ Davies, and Clarebrough, 1967): the valves $\mathcal{N}$ macroscopically were thin and pliable. Tissue fixation at the host-graft junction at two months in case 3 was excellent.

CLINICAL FOLLOW-UP The 20 surviving patients $\frac{0}{3}$ have improved considerably in exercise tolerance. At approximately the expected time intervals after $\stackrel{\mathbb{P}}{\mathbb{P}}$ operation they have returned to work or to house $\stackrel{\square}{\square}$ duties. Except for two patients, cases 6 and 12, 응 


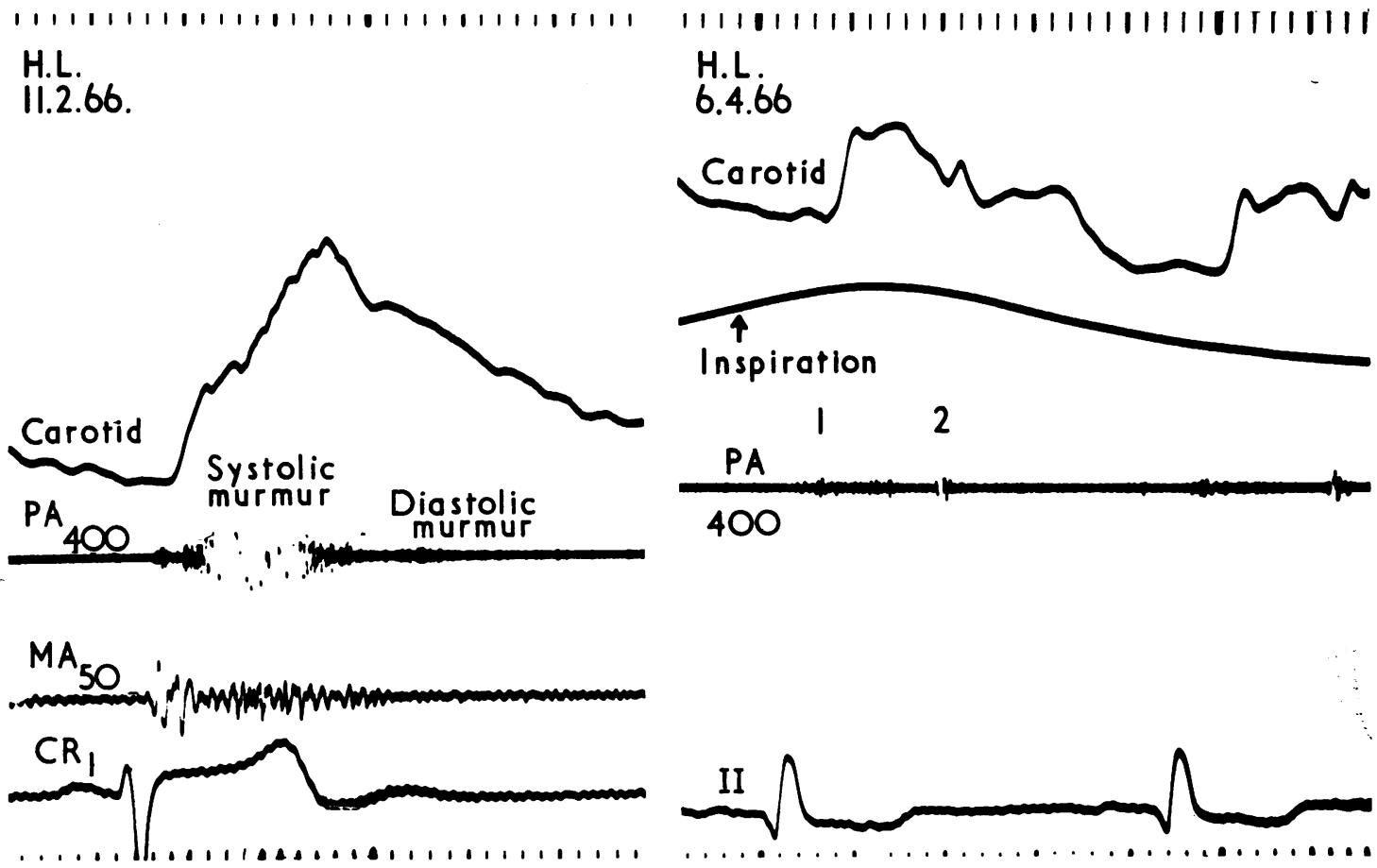

FIG. 3. Case 1. Pre-operative and post-operative phonocardiograms show the comparison in the upstroke of the carotid trace. A soft basal systolic murmur only is just recordable.

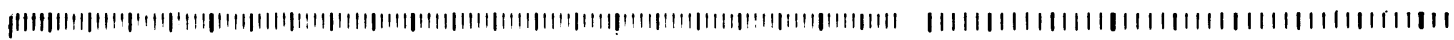

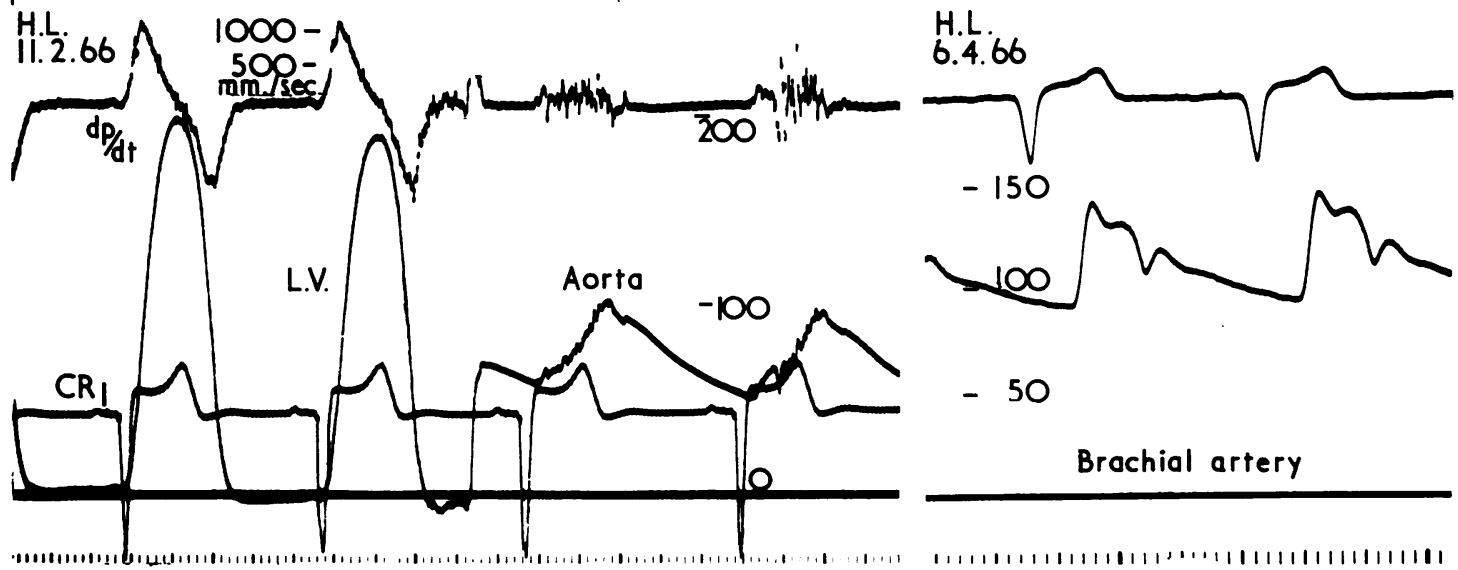

FIG. 4. Case 1. Pre-operative left ventricular and aortic pressures and post-operative brachial arterial trace show the correction of the stenosis. The high arterial diastolic pressure excludes severe incompetence, the absence of which is confirmed by ciné-aortography (Fig. 5B). 
who have some systemic hypertension, all blood pressure recordings are normal. Auscultation and phonocardiography revealed, in most of the patients, normal movement of the second heart sound and a soft, short aortic systolic murmur, the carotid upstroke being normal (Fig. 3). Four patients have no aortic murmurs, and only one patient (case 9) had an aortic diastolic murmur on discharge from hospital. This young girl, who had severe aortic incompetence pre-operatively, has a cuff blood pressure of $120 / 85 \mathrm{~mm}$. $\mathrm{Hg}$ and no peripheral signs of aortic incompetence. At operation after bypass a diastolic thrill was palpable over the aortic root. The loudness of the murmur has diminished markedly over the initial postoperative months, and the transverse cardiac diameter on the chest radiograph has decreased by $2 \mathrm{~cm}$. It is interesting that in this one patient we did not insert a larger heterograft because we had not anticipated that it would be required. In the follow-up period two patients have since developed a soft diastolic murmur, but again without any change in pulse pressure or other signs.

In many of the patients the heart size on the chest radiograph has already decreased and the E.C.G. tracing has shown lessening of the inversion of the $\mathrm{S}-\mathrm{T}$ segments and $\mathrm{T}$ waves.

No clinical evidence of embolism has occurred in any of the patients, including those on anticoagulants because of a mitral ball-valve prosthesis.

HAEMODYNAMIC STUDiES Aortic and right heart pressure measurements, cardiac outputs, and cinéaortograms have been performed in three patients so far (cases 1, 4, and 6) (Table III). There has been a reduction in mean pulmonary artery and wedge pressures at rest. The rapid upstroke of the arterial pulse, indicating relief of the obstruction is seen in Figure 4.

Left ventricular pressures were not measure because of concern that the catheter might cause damage to the recently inserted heterograft. For reasons as yet unknown, the mean systemic blood pressure was higher than the expected norma $\vec{\omega}$ There has been considerable improvement i⿱乛龰 cardiac output in cases 4 and 6 , whereas that of case 1 has remained unchanged, the pre-operative level being normal.

Ciné-aortograms in three patients, none of whom has clinical evidence of aortic incompe tence, are illustrated. The ciné films demonstrate no incompetence in case 1 (Fig. 5), a 'puff' of regurgitant dye in case 6 (Fig. 6), and a mild in $\varnothing^{\circ}$ competence in case 4 (Fig. 7). These ciné frames have been taken at the maximum aortic opacifica 3 tion during diastole. Figure $7 \mathrm{~B}$ represents the maximum amount of incompetence and this is considered mild. The brisk opening of the valvg cusps and the wide orifice were clearly obvious in all three studies. The pre-operative ciné-aortogranष of each case is shown for comparison.

In case 6 , who had aortic incompetence an

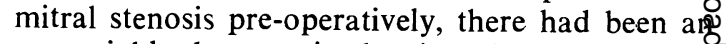
appreciable decrease in the size of the left ventri cular chamber (Figs 8A and B) following hetero graft aortic valve replacement and mitral valvo응 tomy. This change has occurred in spite of the expected increased size of the left ventricula cavity after mitral valvotomy. Possible errors due to different radiographic magnification werf excluded by finding that corresponding ribs were of identical width in both ciné-angiograms.

The appearance of the aortic root and hetero graft valve in Fig. 7B suggests that there is exces

T A B L E I I I

HAEMODYNAMIC STUDIES

\begin{tabular}{|c|c|c|c|c|c|c|c|c|c|c|c|}
\hline \multirow{2}{*}{$\begin{array}{l}\text { Case } \\
\text { No. }\end{array}$} & \multirow{2}{*}{ Diagnosis } & & \multicolumn{2}{|c|}{ Mean P.A. } & \multicolumn{2}{|c|}{$\begin{array}{l}\text { Mean P.A. } \\
\text { Wedge }\end{array}$} & \multirow{2}{*}{ L.V. } & \multirow{2}{*}{ Aorta } & \multicolumn{2}{|c|}{$\begin{array}{l}\text { C.O. } \\
(1 . / \mathrm{min} .)\end{array}$} & \multirow{2}{*}{$\begin{array}{c}\text { Ciné-aortograms } \\
\text { (post-op. valve functio }\end{array}$} \\
\hline & & & Rest & $\begin{array}{l}\text { Exer- } \\
\text { cise }\end{array}$ & Rest & $\begin{array}{l}\text { Exer- } \\
\text { cise }\end{array}$ & & & Rest & $\begin{array}{l}\text { Exer- } \\
\text { cise }\end{array}$ & \\
\hline 4 & Calcific A.S., A.I. & $\begin{array}{l}\text { Pre-op. } \\
\text { Post-op. } \\
\quad 3 \text { mths }\end{array}$ & $\begin{array}{r}22 \\
8\end{array}$ & $\overline{23}$ & $\begin{array}{r}12 \\
0\end{array}$ & $\overline{6}$ & $\begin{array}{c}190 / 10 \\
\text { Not measured }\end{array}$ & $\begin{array}{c}90 / 50 \\
131 / 76 \\
\text { (mean 107) }\end{array}$ & $\begin{array}{l}3 \cdot 2 \\
4 \cdot 3\end{array}$ & $\overline{5 \cdot 4}$ & $\begin{array}{l}\text { Mild incompetence } \\
\text { (Fig. 7) }\end{array}$ \\
\hline 6 & $\begin{array}{l}\text { A.I., M.S., mild } \\
\text { C.A.D. }\end{array}$ & $\begin{array}{l}\text { Pre-op. } \\
\text { Post-op. } \\
4 \text { mths }\end{array}$ & $\begin{array}{l}28 \\
16\end{array}$ & $\begin{array}{l}35 \\
34\end{array}$ & $\begin{array}{r}15 \\
5\end{array}$ & $\begin{array}{l}35 \\
15\end{array}$ & $\begin{array}{c}175 / 12 \\
\text { Not measured }\end{array}$ & $\begin{array}{c}170 / 45 \\
175 / 70 \\
\text { (mean } 110 \text { ) }\end{array}$ & $\begin{array}{l}3 \cdot 6 \\
4 \cdot 8\end{array}$ & $\overline{4 \cdot 8}$ & $\begin{array}{l}\text { L.V. cavity size } \\
\text { 'Puff' of incompetend } \\
\text { (Fig. 6) }\end{array}$ \\
\hline 1 & $\begin{array}{l}\text { Calcific A.S., A.I., } \\
\text { mild C.A.D. }\end{array}$ & $\begin{array}{l}\text { Pre-op. } \\
\text { Post-op. } \\
6 \frac{1}{2} \text { mths }\end{array}$ & 12 & $\begin{array}{l}22 \\
27\end{array}$ & $\begin{array}{l}5 \\
3\end{array}$ & $\overline{12}$ & $\begin{array}{c}200 / 0-5 \\
\text { Not measured }\end{array}$ & $\begin{array}{c}100 / 55 \\
133 / 80 \\
\text { (mean } 100 \text { ) }\end{array}$ & $\begin{array}{l}3 \cdot 75 \\
3 \cdot 9\end{array}$ & $\begin{array}{l}5 \cdot 7 \\
5 \cdot 6\end{array}$ & $\begin{array}{l}\text { No incompetence } \\
\text { (Fig. 5) }\end{array}$ \\
\hline
\end{tabular}

P.A. = Pulmonary artery; L.V. = left ventricle; C.O. = cardiac output. Pressures in $\mathrm{mm} . \mathrm{Hg}$; base line for pressure, sternal angle. 


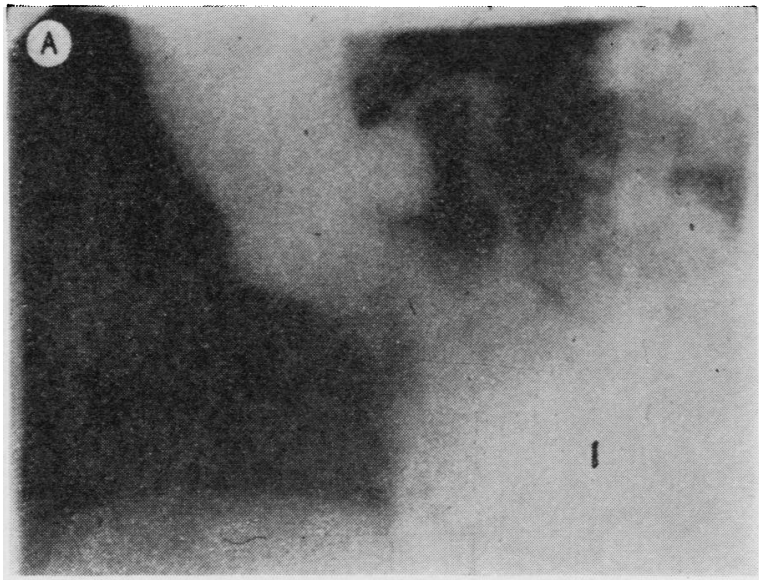

FIG. 5. Case 1. (A) Pre-operative cinéaortogram outlines the degree of regurgitation which fills the whole of the left ventricular cavity. The valve is partly calcified, stenosed, and immobile (L.V.-aortic peak systolic gradient $100 \mathrm{~mm}$. $\mathrm{Hg}$ ). (B) Post-operative examination at six and a half months demonstrates a completely competent valve. (C) During left ventricular ejection the valve opens rapidly and widely as the dye is cleared from the aortic root.
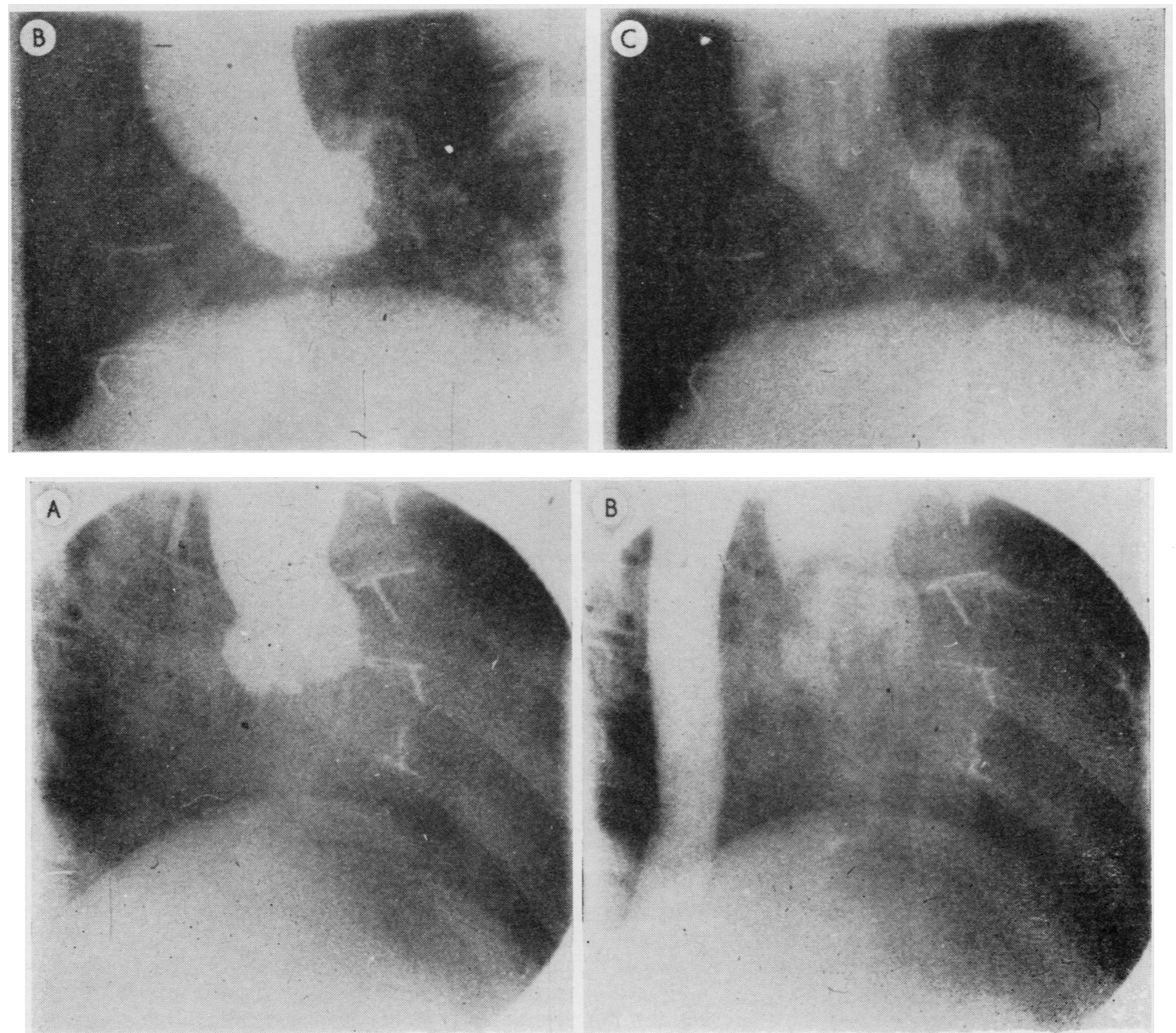

FIG. 6. Case 6. (A) Post-operative ciné-aortogram shows a 'puff' of regurgitant dye during the phase of maximum opacification in diastole. (B) The heterograft valve opens rapidly, demonstrating pliable cusps. 


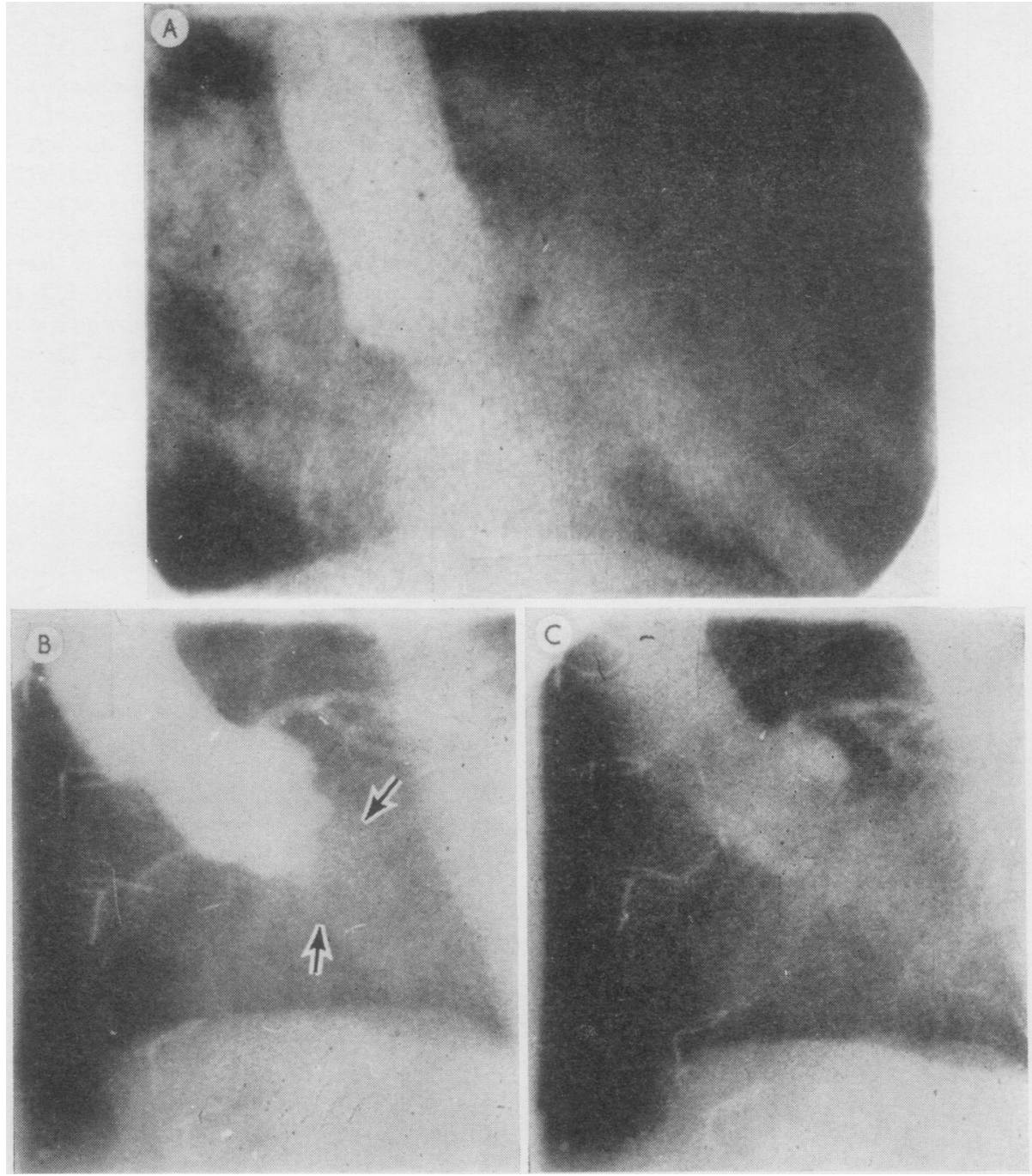

FIO. 7. Case 4. (A) Pre-operative aortic incompetence through a calcified, stenosed valve was seen in the pre-operative ciné-aortogram. (B) Post-operatively, the aortic incompetence is mild (arrows) and is not detected clinically. This frame of the cine film is selected to show the maximum degree of regurgitation. The cusps of the heterograft appear to prolapse a little, suggesting some redundancy of leaflet tissue during valve closure. (C) The valve opens widely during systole.

leaflet tissue which prolapses slightly into the left ventricular cavity. In Fig. 2 a suggested reason for this appearance is illustrated. After excision of ventricular muscle, the right and, to a lesser extent, the non-coronary cusps are increased in breadth (Fig. 2B). The cusps are below a line drawn through the aortic rim on each side and appear prolapsed as in the diagrammatic represen- $-\infty$ tation of the aortogram (Fig. 2C). By suturing the heterograft commissure a little higher up the hostō aortic wall, the cusps are 'hitched' up, minimizing or preventing this prolapse. We hope to restudy this patient after another year in order to deter-음 mine any change in the appearances of the cusps. 


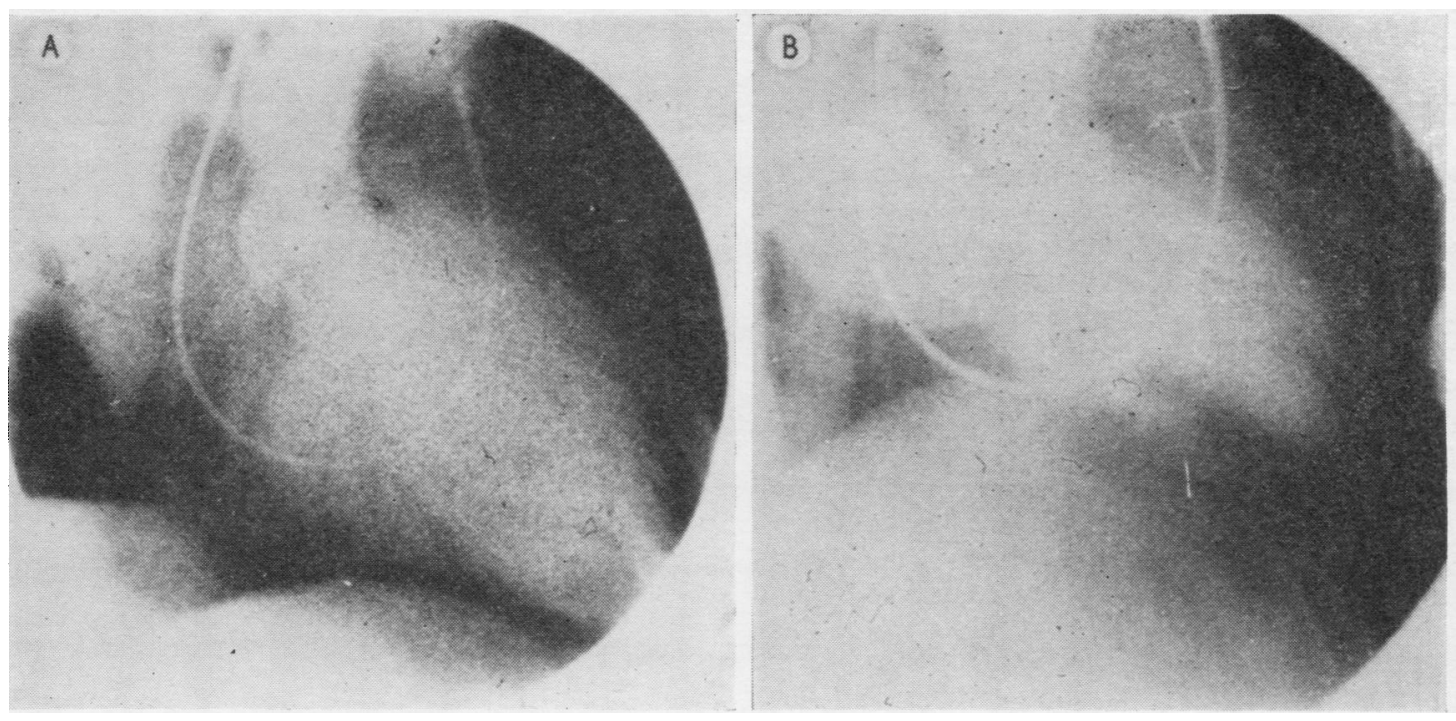

FIG. 8. Case 6. (A) Pre-operative ciné-aortogram demonstrates severe incompetence with opacification of the whole of the left ventricular cavity. (B) Post-operative forward angiogram from the pulmonary artery outlines the left heart chambers and aortic root. The left ventricular cavity shows considerable reduction in size four months after operation (see text).

\section{DISCUSSION}

The heterografts have been used in patients with severe symptomatic disease and this explains the high proportion of patients with double valve replacements in this series. We have been impressed by the improvement of the patients, by the clinical evidence of normal aortic valve function, and by the valve movements as seen on angiography.

FATE AND PRESERVATION There has been no case of valve dehiscence or late failure, although the follow-up has not been long (five to 14 months). Close observation of these patients will be necessary.

In vitro tests of the tensile strength of heterograft valve tissue have not been performed, since we think that such tests are not entirely applicable to the in vivo function and fate of the valve. We think there occurs on the heterograft valve some early fibrinous and cellular deposition which may contribute to its tensile strength. We think that later there is endothelialization, though Smith (1967) did not find any true endothelialization on homografts.

Buffered acid formaldehyde has been selected as the preservative and sterilizing agent. Because of the ready availability of heterograft valves, and because of the simplicity of this method of preservation and sterilization, the establishment of a valve bank has presented no major problem. To our knowledge there has been only one published report of the use of a formaldehydepreserved valve (Paneth and O'Brien, 1966): this was a homograft. In this patient aortic regurgitation of mild degree developed on the tenth postoperative day. Re-operation because of increasing valve incompetence was performed three and a half years later. Considerable disorganization of the valve had evidently occurred. This valve had been subjected to abnormal haemodynamic stresses and no conclusions regarding the influence of formaldehyde preservation on the subsequent valve degeneration in this single case can be reached. Nevertheless, some caution is exercised in recommending formaldehyde preservation. A critical review of the various available techniques will be necessary.

IMMUNOLOGICAL REACTION There are several reasons why there is no host reaction against the transplanted heterograft aortic valve. Firstly, the valve tissue probably has a low content of transplantation antigens (Nossal and Mackay, 1966). This is because the tissue, being composed predominantly of collagen and elastic fibres, is poor in cell membrane constituents. Secondly, the preservation in formaldehyde with the consequent 
denaturation of tissue proteins could reduce the antigenicity even further. Thirdly, the graft is a non-living tissue and receives no blood supply.

RESISTANCE TO THROMBO-EMBOLISM Since it is known that platelets adhere to connective tissue in vitro (Hovig, 1963), and in vivo (Spaet and Zucker, 1964), the possibility existed that platelets might adhere to the exposed connective tissue of the heterograft. However, in vitro studies failed to demonstrate adherence of platelets to the homogenized valves (Hirsh, 1966), presumably because the collagen had been denatured during preservation. Increased platelet adhesiveness has been found in the majority of our patients with prosthetic aortic ball-valve replacements but not in those with heterografts (Hirsh, Clarebrough, and O'Brien, 1967). Although the significance of these observations is uncertain, it may be related to the different incidence of thrombo-embolism in these two groups.

\section{REFERENCES}

Barratt-Boyes, B. G. (1964). Homograft aortic valve replacement in aortic incompetence and stenosis. Thorax, 19, 131.

Lowe, J. B., Cole, D. S., and Kelly, D. T. (1965). Homograft valve replacement for aortic valve disease. Ibid., 20, 495.

Bigelow, W. G., Yeo, J. K., Aldridge, H. E., Heimbecker, R. O., and Murray, G. D. W. (1964). Clinical homograft valve transplantation. J. thorac. cardiovasc. Surg., 48, 333.

Binet, J. P., Duran, C. G., Carpenter, A., and Langlois, J. (1965). Heterologous aortic valve transplantation. Lancet, 2, 1275.

Hirsh, J. (1966). Personal communication.
- Clarebrough, J. K., and O'Brien, M. F. (1967). In preparation. Hovig, T. (1963). Aggregation of rabbit blood platelets produced in vitro by saline 'extract' of tendons. Thrombos. diathes. haemorrh. (Stuttg.), 9, 248.

Kerwin, A. J., Lenkei, S. C., and Wilson, D. R. (1962). Aortic-valve homograft in the treatment of aortic insufficiency. New Engl. J. Med., 266, 852 .

Murray, G. (1956). Homologous aortic-valve-segment transplants as surgical treatment for aortic and mitral insufficiency. Angiology, 7,466 .

Nossal, G. J. V., and Mackay, I. R. (1966). The Walter and Eliza Hall Institute of Medical Research. Personal communication.

O'Brien, M. F. (1967). Heterograft aortic valves for human use: valve bank, techniques of measurement, and implantation. $J$. thorac. cardiovasc. Surg., 53, 392.

- and Clarebrough, J. K. (1966). Heterograft aortic valve transplantation for human valve disease. Med. J. Aust., 2, 228. - (1967). Heterograft aortic-valve replacement. Lancet, 1, 929. Davies, A., and Clarebrough, J. K. (1967). In preparation.

Paneth, M., and O'Brien, M. F. (1966). Transplantation of human homograft aortic valve. Thorax, 21, 115.

Ross, D. N. (1966). Aortic valve surgery. Ann. roy. Coll. Surg. Engl., $39,192$.

Smith. J. C. (1967). The pathology of human aortic valve homografts. Thorax, $22,114$.

Spaet, T. H., and Zucker, M. B. (1964). Mechanism of platelet plug formation and role of adenosine diphosphate. Amer. J. Physiol. 206, 1267.

\section{ADDENDUM}

Since the submission of this paper for publication, one patient (case 6), who has had systemic hypertension, has presented at 14 months with severe aortic incompetence of sudden onset. Reoperation will be necessary. The other patients remain very well.

Changes in the technique of dissection of the heterograft valve have been made and these, after adequate trial, will be reported. 